Networking Knowledge: Journal of the MeCCSAPostgraduate Network, Vol. 4, No. 1 (2011)

Article

\title{
Mohamed "el-Limby" Saad and the popularization of a masculine code
}

KOEN VAN EYNDE, Netherland-Flemish Institute in Cairo

\begin{abstract}
.
In this paper I investigate the representation of masculinity in contemporary popular Egyptian cinema as portrayed by Mohamed Saad and his immensely popular "el-Limby" character, as well as the variations to it. Mohamed Saad is a very famous Egyptian actor, who has become popular in a short period of time. The paper draws on several key concepts in the study of the identification with star personae in cinema as well as gender studies. Identification with the elLimby character is essential for the popularity of the films. He portrays the image of what could be considered the opposite of masculine characteristics as they are generally defined in Egyptian society. Yet he is sympathetic to the audience and they do not mind identifying with his character(s).
\end{abstract}

The question I address is if and how the construction of a certain type of masculinity is related to both the popularity and decline of the characters. To address this question, we analyze and construct the masculinity in the el-Limby movies and their variations. The paper then explores how these variations have worked to create a sense of estrangement in the audience, which is verified by the movies' decline in popularity.

\section{Key words}

Masculinities, cinema, Egypt, identification, gender 
Networking Knowledge: Journal of the MeCCSAPostgraduate Network, Vol. 4, No. 1 (2011)

When we talk about Mohamed Saad (b. 1968), one of the most famous actors in Egypt in the last decade, one thing is certain: he incites strong feelings in both his supporters and his adversaries. His opponents sometimes refer to him as the symbol of the decline of Egyptian cinema. Others simply enjoy his sense of humor and specifically the typical character he puts forth in most of his movies (Moosa 2002; Atef 2006; Abd el-Fattah 2007).

Mohamed Saad is from a popular neighborhood in Cairo, close to Sayeda Zaynab. ${ }^{1}$ This background is cast into most of his characters. He is also a graduate from the Higher Institute of Drama in Giza, an old and renowned academy of the arts. Saad graduated performing Shakespeare's play “Julius Caesar". He started his acting career in the eighties, when he was playing small parts in a theater in his neighborhood, the Center of the Youth of Habbaniyya. He starred in several soap operas and theatrical plays. His first appearance on the big screen was in 1995 (The Road to Eilat, Enaam Mohamed Ali), but his breakthrough was with the character el-Limby in 2000 (Principal Salah el-Din, Sherif Arafa).

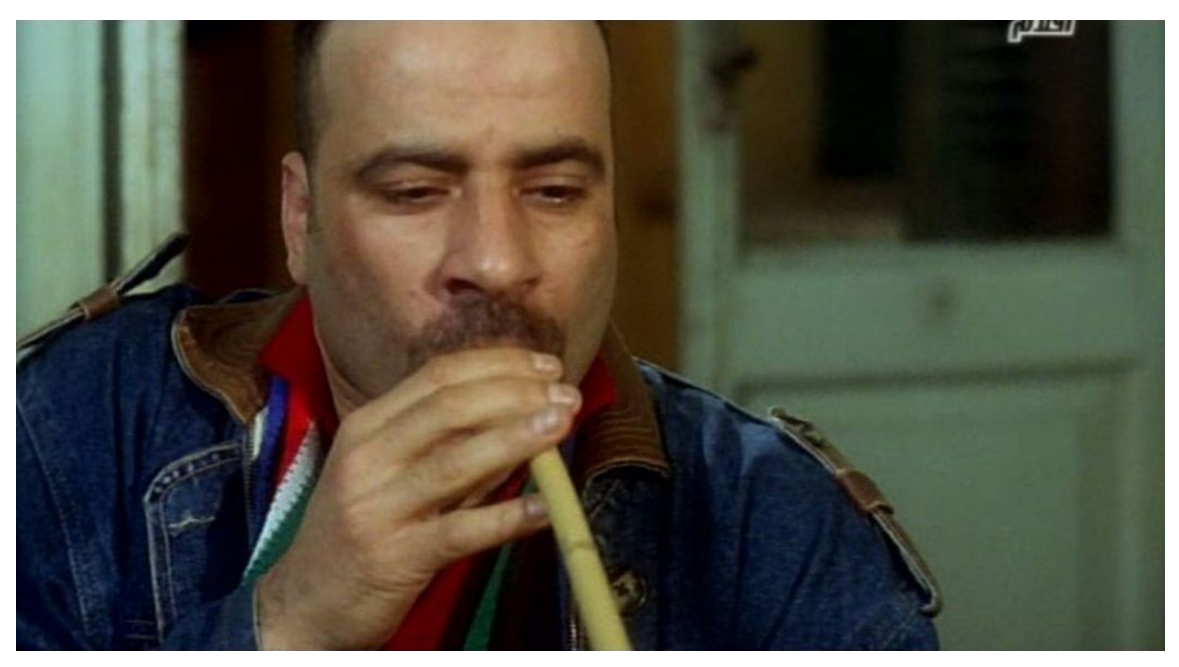

Figure 1: Mohamed Saad smoking hashish in El-Limby

Mohamed Saad himself proposed to the director the specific style of the Limby-character - a man with a speaking disorder, uneducated, continuously drunk or on drugs - which was very

${ }^{1}$ A popular area close to the mosque with the same name, to the south-east of downtown Cairo. 
well received by the public. This is how the Limby-character was born and as little as two years later his movie El-Limby (Wael Ihsan 2002) topped the box office rankings and in its first week accumulated the highest earnings ever (in absolute numbers) in Egyptian film history. ${ }^{2}$ His popularity even goes so far as that an older movie in which Saad played only a secondary character (el-Gentel, Ali Abdel Khalik, 1996), is now promoted as being a 'Mohamed Saad'-movie. He continued to top the rankings until 2006, the year in which he had to compete with another immensely popular film (The Yaqoubian Building, Marwan Wahid Hamed 2006), however he never managed to improve the all-time record El-Limby reached.

This brings us to the topic of this paper: the masculinity of Saad's characters and the movies' popularity. The Limby-movies earned millions of Egyptian pounds, yet their popularity has waned. Why did the audience grow tired of seeing these types, although Mohamed Saad tried to avoid repetition by bringing variations to el-Limby with different backgrounds and in different settings. ${ }^{3}$ I will then relate this question to the issue of identification with star personae in movies and how this identification can "break down when those representations fail to satisfy the needs of that audience" (Shail, 2001: 98). The main focus in the analysis is on a particular construction of a masculine code in his movies. Parodying the presented masculinity is a central theme in all his movies. The study of Limby's masculinity could be part of the explanation of the characters' popularity and decline.

Before presenting the analysis, I will clarify some key elements concerning the construction of gender in movies as well as how identification is established between the audience and the star persona. Then I will briefly outline the applied framework for analysis.

\section{The construction of gender in film}

\footnotetext{
${ }^{2}$ Data retrieved from http://www.hdrmut.net/vb/t126457.html (accessed March 31, 2011).

${ }^{3}$ The reason for stating that his popularity declined, is that box office results went down. What should also be taken into consideration is that more and more people have high-speed internet connections and downloading pirated versions of movies is very common. To have a better picture on whether his popularity actually declined, we should also consider the number of times that a Mohamed Saad film is downloaded or a pirated version (illegally) sold. These numbers are of course not available, so we will have to stick to box office results for the time being as well as interviews with the actor and articles mentioning the downward trend.
} 
Judith Butler (2002) points out several elements in the construction of gender, focusing specifically on its relationship to culture, its historicity, and the social context: "gender is an identity tenuously constituted in time, instituted in an exterior space through a stylized repetition of acts" (Butler 2002: 179). Gender is therefore understood as a performance, a series of acts. Butler labels these performative acts as fantasy. Fantasy is the playground where other, subversive, performances of gender identities are on display. The argument of main interest here is the redefinition of parody. As Butler understands it, gender parody here constitutes mocking the notion of an original: "gender parody reveals that the original identity after which gender fashions itself is an imitation without an origin" (Butler 2002: 175). Parody thus is a way of reclaiming the field of gender identity away from hegemonic ${ }^{4}$ notions of gender. Studying parodic constructions of these perceived original gender identities accordingly offers insight into what these 'originals' are thought to be, or what could be described as the gender ideology in a certain culture.

The critique of gender ideology has been advanced by feminist research and it is also useful for my analysis of masculinities in films. I take here as a basis Cynthia Freeland's proposed framework for a feminist reading of horror movies. As Freeland pointed out, movies should be viewed as artifacts "that may be studied by examining both their construction and their role in culture" (Freeland 1996: 204). This means that we should look at how technical features (like plot, characters, point of view, as well as sound, editing, costumes, etc.) are used to construct gender ideologies. Freeland, understanding 'ideology' from a Marxist perspective, defines it as a certain view on natural and unchanging power relations. What I want to study in the films is how the medium presents these power structures and relations.

But Freeland goes further than just looking at what is represented in the movies-asartifacts. She holds that it is equally important to look at what is omitted and avoided. Part of the film's ideology is indirectly conveyed through a lack of particular images: what is not exposed, can be at least as informative as what is explicitly shown. I understand this as looking for what

\footnotetext{
${ }^{4}$ Connell has defined hegemony as "the successful claim to authority", where "violence often underpins or supports authority" (Connell, 2005: 77). We will see in the analysis of the movies that violence is an essential part of the characters' perceived notion of masculinity.
} 
Networking Knowledge: Journal of the MeCCSAPostgraduate Network, Vol. 4, No. 1 (2011)

David Bordwell (1989) has called 'symptomatic meanings'. These are actually extra-filmic meanings brought unto the film by the audience or the critic. They constitute a deeper reading of the movie, past the explicit elements, in order to discover "economic, political, or ideological processes" (Bordwell 1989: 9). Although Bordwell does not consider these meanings to be the center of a movie analysis they do add valuable information to hiatus in the analyst's understanding of the film.

\section{The identification with a star persona}

Throughout the analysis I will approach the question of identification from a cognitive perspective. Although some cognitive film theorists and philosophers have rejected the notion of identification (Bordwell 1996: 15; Carroll 1990: 96), Berys Gaut (2006) on the other hand argues it can fit a cognitive framework. He disagrees with a monolithic understanding of identification and instead proposes an aspectual approach to the concept. As Gaut notes, imagining oneself to be in the character's position calls attention to the aspects with which one identifies. A character is constructed with certain properties, both physical and psychological. The physical properties concern the outer appearance of the character and the situation he is in. The psychological properties consist of the character's visual, motivational, affective, or epistemic perspectives on the world around him. Thus each member of the audience will identify with specific aspects of the character, depending on his or her background or understanding of the movie.

I argue that a partial identification with the characters is necessary for their popularity. Which aspect of identification depends on the specific member in the audience and is however not the goal of this paper to investigate. Saad's characters became more and more estranged or alienated from the expectations the audience has. I will discuss this estrangement and alienation from the perspective of the characters' masculinity.

\section{The analysis of Mohamed Saad's movies}


Networking Knowledge: Journal of the MeCCSAPostgraduate Network, Vol. 4, No. 1 (2011)

Before continuing, I need to point out a few practical details concerning the movies discussed here as well as the interview conducted with a member of the audience (and a fan of Mohamed Saad for that matter). First of all, when analyzing Saad's films we must always keep in mind that they are made with a clear commercial goal. These films are produced to make people laugh and feel good, so that they would buy a ticket to enter the cinema (and do so again when the next movie comes out). Also important for an analysis of gender ideologies as presented in these movies, is the fact that Mohamed Saad considers his films to be "clean cinema". ${ }^{5}$ The label was applied in the nineties to certain films which avoided the 'hot' topics sex, religion, and politics (Shafik 2007; Karawya 2010; Armbrust 2011). In the case of Saad's films this means that he avoids a discussion on the topics altogether offering slapstick family comedies. This is particularly important when analyzing the relation between Saad's characters and the world around him - specifically the women in his surroundings.

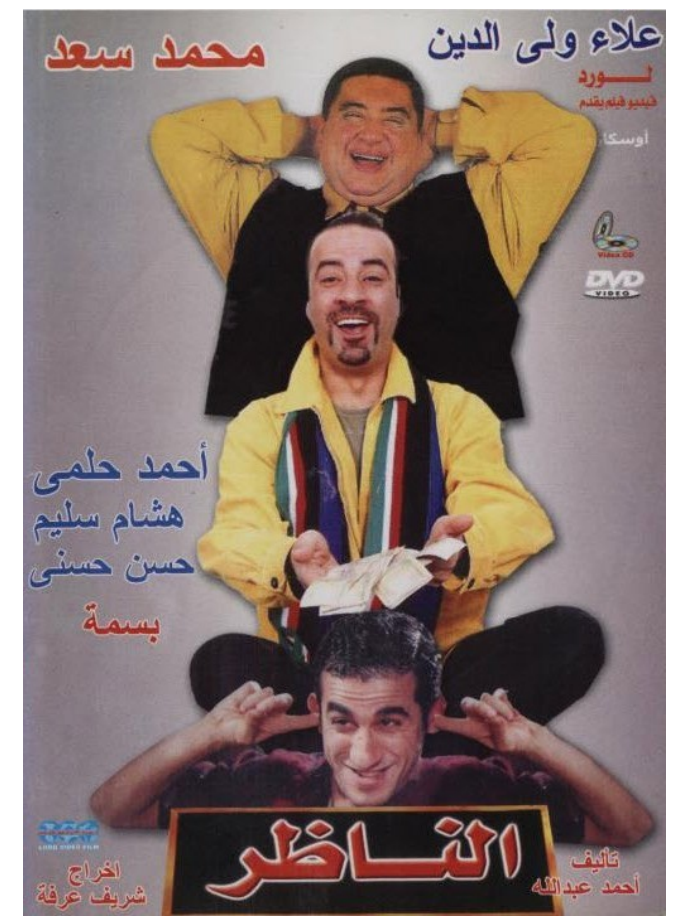

Figure 2: Mohamed Saad, Alaa Waly el-Din and Ahmed Helmy in Principal Salah al-Din

\footnotetext{
${ }^{5}$ Interview Ahmed Farouk with Mohamed Saad in Shorouk newspaper, 7 July 2010.
} 
Secondly, the analyzed movies are not all the films that Mohamed Saad played in. I will start with the first three Limby-movies, Principal Salah al-Din (Sherif Arafa, 2000), El-Limby (Wael Ihsan, 2002) and Do You Remember? (Wael Ihsan, 2003). Although in Principal Mohamed Saad was only playing a secondary character, it was the first time his Limby-character appeared on screen so it would have been impossible to leave this movie out. I will then take later movies ${ }^{6}$ as points of reference to compare in what sense the characters have developed over the years. The reason is that the first three movies all involve the character el-Limby, while the more recent films show Mohamed Saad as a similar character, but in different roles and backgrounds.

I did not include his earlier movies, since their storyline and characters are entirely different. These films are not meant to be comic or stereotypical; nor does he play major roles. His last two films, Boshkash (Ahmed Yousry 2008) and El-Limby 8 Giga (Ashraf Fayek 2010), were also not included in the analysis. His latest movie, El-Limby 8 Giga was simply not yet available on DVD on the time of analysis. Boshkash was not taken into account because Mohamed Saad presented here a completely different type: educated, well-spoken, rich. Although it was a comedy, the film's narrative distinguished itself from his earlier slapstick movies in that it incorporated two main characters (Mohamed Saad and actress Zeina) whose separate storylines would eventually come together. This is different from his other films in which he is the only main character and all events concern his character.

Analyzing the movies was not always optimal, since the recording quality of DVD's is quite bad. The movies are actually sold in a VCD format and often the sound and images are not synchronized. Obviously analyzing movies in this situation is quite fastidious and annoying. Another disadvantage of having to watch the movies at home, is that I was unable to measure the audience's reaction to the films. I was limited to articles, interviews and box office results to study the development of Saad's films.

\footnotetext{
${ }^{6}$ The later movies are Awkal (Mohamed el-Naggar, 2004), Booha (Ramy Imam, 2005), Katkoot (Ahmed Ewaad, 2006) and Karkar (Ali Ragab, 2007). All of them are different characters, the title of the movie being the name of the character.
} 
Networking Knowledge: Journal of the MeCCSAPostgraduate Network, Vol. 4, No. 1 (2011)

After finalizing the analysis, I also interviewed a member of the target audience, named Mahmud. He is an unmarried young man, though engaged for two years now and from the same neighborhood as Mohamed Saad. One interview is limited; nevertheless it puts the analysis into a different perspective. Adding to the interview, I also conducted informal talks with friends (both male and female) about the films, which helped me fill in the gaps in my understanding of the films. These talks were helpful in understanding certain elements in a local context and not just from the point of view of the foreign researcher. They also provided me with valuable information on how Egyptians experience these movies and their emotional responses to them.

\section{A masculine code?}

As noted in the introduction, Mohamed Saad brought Egyptian cinema a new image of men. His construction of 'man' on the big screen can at least be labeled as subversive. Contrary to Sawsan el-Messiri's description of ibn al-balad (literally 'child of the country'), Mohamed Saad's characters could be seen as a redefinition or an impersonation of this 'child of the country'. El-Messiri describes ibn al-balad as "alert, intelligent, quick-witted, masculine, jovial, independent and extrovert" (el-Messiri 1978: 54). This description of the ibn al-balad is questioned in the movies through parody, an analysis of which might offer insights into what Mohamed Saad and his characters think about idealized notions of masculinity.

Kirkham and Thumim (1993) have offered a useful framework in their study "You Tarzan" for investigating the representation of masculinities in cinema. They put forward several categories related to film genre in distinguishing between certain masculine representations. I decided to break up the masculine image Saad proposes, but not from the perspective of genre, but rather from the point of view of the character himself. For this I applied Gaut's notion of aspectual identification to the character's personality. I created four categories to describe el-Limby, namely his physics and looks, his inner feelings and emotional responses, his social background and understanding of the world around him, as well as his relationship with others and more specifically with women. Simultaneously I will outline some of the differences between el-Limby and its variations. 
Networking Knowledge: Journal of the MeCCSAPostgraduate Network, Vol. 4, No. 1 (2011)

\section{Masculine looks}

The first thing we want to ask ourselves is how el-Limby is presented as a man. As pointed out earlier, his masculinity does not reflect a common representation of men on screen. He is not the strong good-looking male hero, fighting and vying for the hand of his lover. He is actually the exact opposite of this and it was the first time that such an image of an 'anti-man' was presented in a film while being the 'hero' of the movie. ${ }^{7}$ The first impression we get of el-Limby is that of a poor man, uneducated, stupid, addicted to drugs and alcohol, and without any taste in clothes or accessories. Essential are attributes like pocket knives, cigarettes, and the occasional bottle of locally brewed whisky. But let us have a closer look, past the clothes, accessories and drinks.

A constituent factor in Mohamed Saad's films is hair. In Do You Remember? he looks with great appreciation at his chest hair, very proud of what he has on offer. El-Limby always has a distinct moustache, just like the other characters. The moustache as a symbol of manhood is very famous indeed in the Middle East (Gilmore 1990: 31; Daoud 2006). The moustache is almost a personification of manhood and without it, a man loses his honor. This is most obviously shown in Katkoot (Ahmed Ewaad 2006). ${ }^{8}$

\footnotetext{
${ }^{7}$ An actor like Ismail Yassin in the old days, or Mohamed Heneidi nowadays also bring images of 'anti-heroes' in their films, however their types are from entirely different backgrounds and are never shown as drug addicts or low class men looking for work and money. Their characters' masculinity is not questioned the same way as especially El-Limby is doing.

${ }^{8}$ See also the section Relation with the world: Katkoot's dramatic emphasis on his hair as part of his masculine honor is in stark contrast with his disinterest in the family's honor.
} 


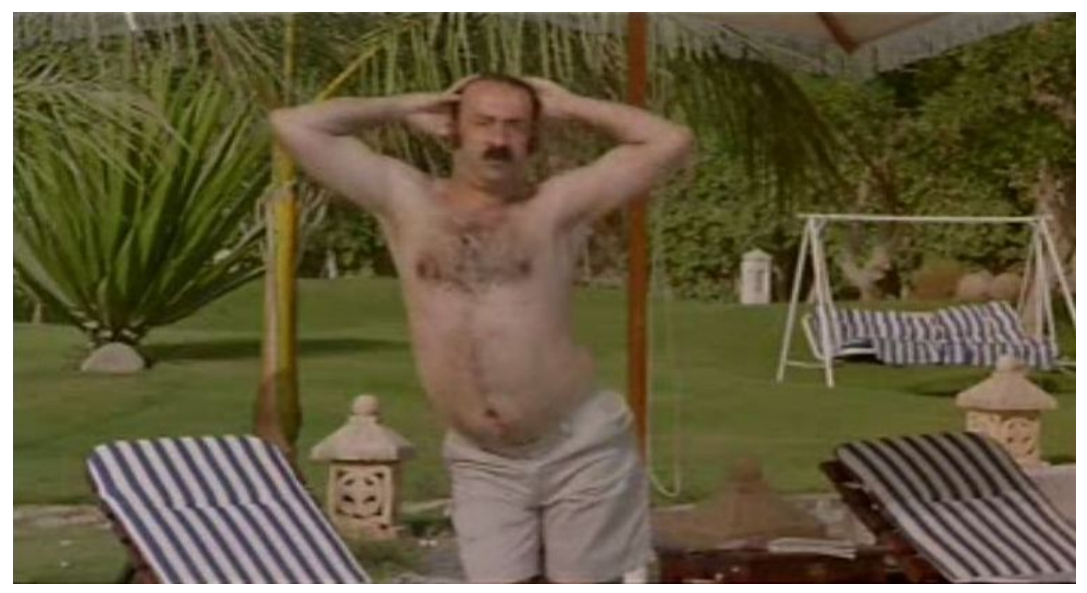

Figure 3: Warming up for a swim in Katkoot

In this movie, Katkoot has grown a defined thick moustache, including whiskers, which he literally lauds in the beginning of the film while smoking hash with his friend: he touches his upper lip with great emphasis, pulling forward his moustache which almost fills the screen. Later in the same movie he needs to cut his facial hair in order to pass for a westernized Arab (also played by Mohamed Saad). This scene underlines once more the importance of his moustache (which he calls 'ras arrujula', the apex of masculinity), when he panics and cries each time the scissors get closer. He dramatizes the whole scene by taking of his shirt and offering to cut his chest hair 'while you're at it' and then takes off his pants to continue with his legs as well. This is of course an exaggerated account of the importance of hair, not to mention the comedy of the scene, but it nevertheless proves it is essential for Saad's characters' masculinity.

Another element in el-Limby's appearance is the objectification of his body. He shows off his unattractive body on many occasions. In doing so, he practically feminizes it. Almost erotic belly dancing is part of every film and every character. It is essential for his characters to be visible, to be in the center of attention. This fits el-Messiri's description of the ibn al-balad as being jovial and extroverted, as well as Gilmore's reference on Mediterranean masculinity being a performance and "being on view and having the courage to expose oneself to risk" (Gilmore 1990: 36). In the case of el-Limby he is not shy to be on view and in the center of attention, but whenever it gets 'risky' he is nowhere to be seen. 


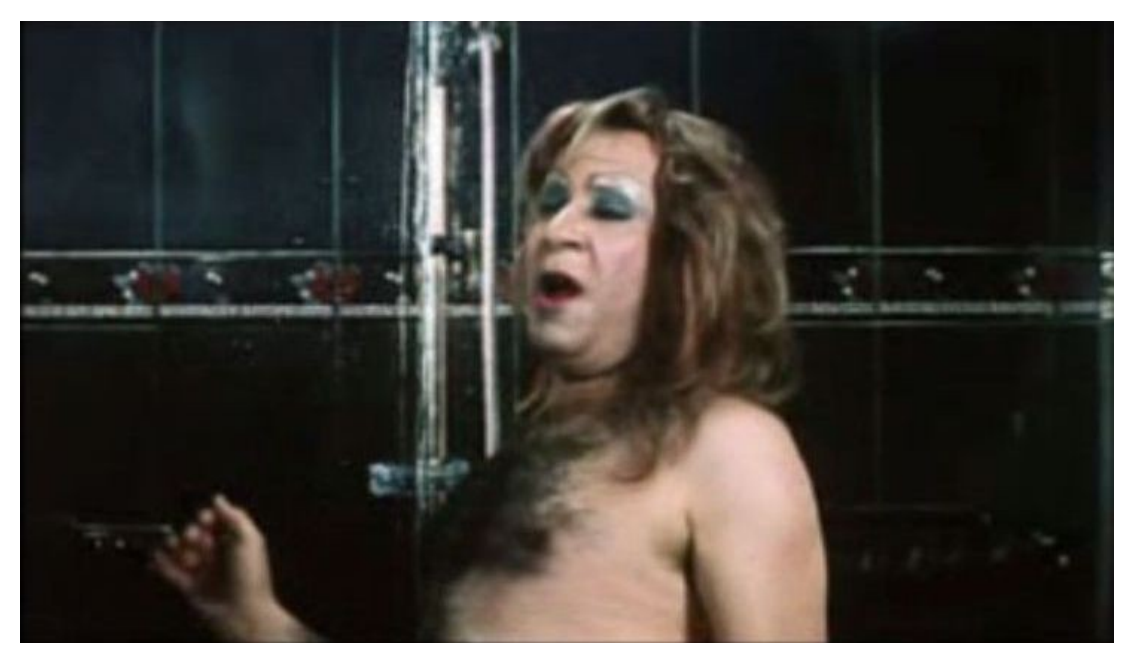

Figure 4: Showering and revealing his true identity to the public and Karkar in Karkar

References to homosexuality also abound in his movies. These references are put forward in comedic settings though in one particular movie Saad is very provocative. In the film Karkar (Ali Ragab 2007) Saad actually plays three different characters. He plays Karkar, who has an accident and looses his mind, as well as Karkar's father and (male) cousin. The dying father wants to keep the riches within the family, therefore he wants to marry his crazy son to one of his (female) cousins. Since his cousin is male, he is dressed up as a woman and is asked to seduce Karkar so that he would marry him/her. Karkar actually discovers his cousin is a man, but still decides to marry him (of course, since Karkar is crazy, he is forgiven by the movie for his 'irrational' decisions). And when Karkar comes out of the nuptial bedroom, the movie even suggests that the marriage between the two men has been consummated!

The topic of cross dressing itself is quite common in Egyptian films, as well as outspoken gay characters. Menicucci's study of gay representations in Egyptian cinema (1998) also mentions cross dressing in comedies as one of the most common representations of gay characters. Homosexual characters are however not always acting in comedies, also in social dramas and other mainstream films homosexuals are present. The film Yaqoubian Building (Marwan Wahid Hamed 2006) included a homosexual as one of the film's main characters. The 
Networking Knowledge: Journal of the MeCCSAPostgraduate Network, Vol. 4, No. 1 (2011)

film showed the man as being part of society, an editor of an established French-language weekly and with friends in high circles. In the end of the movie however the character is murdered as if to ensure society's norms are not being challenged. The same is true for Karkar, where Mohamed Saad is provoking, but does not intend to challenge any norms. In the end everything goes back to normal and the marriage is annulled as soon as Karkar gets his memory back.

\section{Emotions}

As opposed to many Western movies (comedies, action, horror or other genres), men showing emotions openly is a common element in Egyptian films. El-Limby too has no problem with expressing himself, albeit sometimes in an excessive manner - as is fitting in Egyptian comedy. El-Limby is extravagant, outgoing, and childishly expressive, partially due to the effects of drugs and alcohol, but also simply because of his character.

In the movie Principal Salah al-Din the first part of the movie is dominated by grey, dull colors and people not nearly as extravagant as el-Limby. The two co-actors really create tension and build up high expectations in the audience before el-Limby is introduced. They have never had an exciting life (Salah el-Din himself is literally referred to as 'the son of his father' and does not do much except translating foreign series simultaneously into Arabic for his old mother) and are planning to do something 'new' in their lives. They want to become saayie and monharef, useless and deviant, after which the movie cuts to the very brightly colored and loud wedding party of el-Limby.

The movie shows us first an unattractive local belly dancer, then a plate on his wife's lap filled with hashish and pills after which the camera pans towards el-Limby lighting the hash cigarette his wife has prepared for him. The stark contrast between the two scenes as well as the clear and flamboyant differences between the characters mostly has a comedic effect, yet what is of more importance here is the stress the image puts on el-Limby's expressive behavior. When Salah el-Din and his friend Atef enter the wedding, el-Limby invites them to sit next to him in stead of his wife. His newly wed wife runs towards her mother and a fight flares up between her 
father and mother. Her father asks why she accepted el-Limby's money to marry their daughter and both start insulting el-Limby. When he finds out however what they say about him, el-Limby decides to divorce his wife that same moment.

One might argue that these expressions of euphoria do not really prove anything, since it is less confronting than showing tears in public for example. But the character el-Limby shows his audience both. In El-Limby, he cries at home in front of his mother and cries in front of his fiancée, he even runs after her in the streets, crying and shouting in public. All these emotional reactions and outcries are exaggerated, but since his movies are always shot from the point of view of el-Limby, we as an audience have double feelings. We both laugh at the comedic scenes developing in front of us; yet find it sad for the character that whatever he is trying to accomplish is doomed to fail.

There are several reasons for these contradictory feelings. One reason is the fact that the character is very recognizable for many. Mohamed Saad himself claims that there is a little bit of el-Limby in every Egyptian man (Farouk 2010). This is probably a bit of wishful thinking though. ${ }^{9}$ Nevertheless, the last decades have seen a growing gap between the rich and the poor in Egypt, the working class sinking deeper into poverty as well. Many university graduates are unable to find jobs and start a life on their own, causing a growing marriage crisis specially in the cities (EHDR 39). The lack of opportunities, growing poverty, unable to get married, are all issues el-Limby has to deal with, just like many people in his audience.

At the same time we experience him to be the victim of the situation, causing us to sympathize with the character. Another reason is el-Limby's effort to look like the 'ideal man', $S i$ Sayyed, while at the same time making fun of this ideal image. Thus el-Limby as-the-normal-guy is recognizable yet dramatized and parodied, confusing the audience. This confusion adds to the alienation of the audience, which will be dealt with later on in this paper.

\section{Relation with the world}

\footnotetext{
${ }^{9}$ However during the interview and in talks with Egyptian male and female friends, nobody admitted to seeing something of el-Limby in him or herself. Aligning oneself with such an anti-hero is of course not exactly attractive.
} 


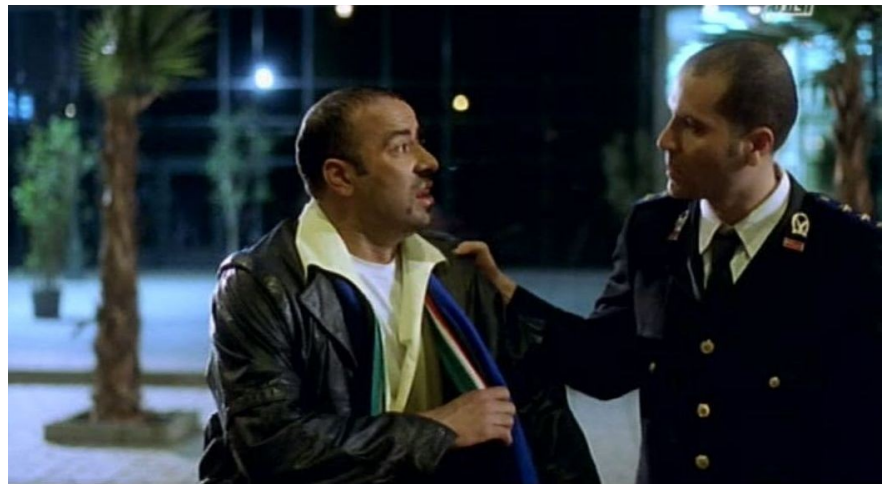

ure 5: El-Limby arrested by the police for walking around in a rich quarter of the city in El-Limby
Since all of his plans seem to be doomed to fail, El-Limby's relationship with everything around him is fatalistic and negative. In the very beginning of El-Limby, when he is walking home drunk and far away from his own neighborhood, we first hear a police siren after which the camera zooms in on his face and we notice a frightened look, hands raised. The

director here emphasizes the feeling many young men have once they leave the protected hara, or neighborhood. They often feel insecure and are afraid of wandering about in a place where they have the feeling they do not belong, or at least the state gives them this feeling (Ismail 2009: 236).

These feelings are also present in el-Limby, who considers his neighborhood a safehaven where he is known, feared and respected. When the worldly threat is entering his neighborhood - first in the person of Naim, whom he borrowed money from; then in the person of the primary school teacher who wants to marry his fiancée - only then is he pushed to look for a job and start making some money. He has the feeling that the world is passing him by, while he has no evident role to play in it. He never has a hand in how his life develops, emphasized by an image of el-Limby on top of a lonely rock somewhere in the desert, shouting "el-Limby fishil ya bani admin" (el-Limby's failed, people!).

The development of each story works in a way that shows the audience how el-Limby is played with by the people around him. The bicycle project was his mother's idea, as well as selling sandwiches in the street, while doing his reading and writing exam was one of the requirements of his fiancée for getting married. Even the marriage itself, the success of which he at first seemed to be in control of (by bringing in the money needed for the wedding), is subsequently put on hold by his father-in-law and Noosa, his fiancée. It is finally his mother and Noosa who agree together on the wedding, while el-Limby himself has no right to intervene - he is sent outside while the two women agree on the details. 
Decisions made by others also dominate his look on the world around him in other films and not just El-Limby. In Katkoot we first hear the group of elders in some southern Egyptian village discuss what to do with 'Katkoot' before we actually see him. The elders decide that it is in the community's advantage that Katkoot is killed in order to settle an old dispute between two rival families and to maintain both families' honor. When he finds out later what fate has been decided upon, he keeps asking 'why me?', and eventually tries to run away. Remembering his theatrical drama about masculinity and honor when the barber tried to shave his moustache, the two scenes are contradicting Katkoot's perception of masculinity.

But who are the people governing his life and is there a pattern? As we have seen already, in El-Limby his mother is the overwhelming figure, dominant and powerful, respected in the neighborhood. She controls her son's future since he is still dependent on her. Remarkably, however, most of his family is absent in the other movies. In Principal, he is completely alone on his wedding night; el-Limby's father in El-Limby has passed away some time ago; and in Do You Remember?, he is without any close relatives. The same is true for more recent films. And if there is family around (aunts or uncles), they are the cause of trouble. What could this mean, and how could we interpret this?

As Gilmore (1990) has observed, masculinity in the Mediterranean consists of three basic elements. A man needs to impregnate, provide and protect. El-Limby does however none of the above. He fails on all 'levels of manhood' and blames others for it. He obviously does not consider his own actions - drinking, doing drugs, hanging around - to be (part of) the reason. On the contrary, as a man he thinks he needs to be able to drink a lot, hang out with his friends and be sociable. This is why, in Do You Remember?, he replies to the question why he does not look for a job with "I don't have time!". Posing this question to someone in prison - as el-Limby is is rather sarcastic, therefore his answer is quite blunt.

But Gilmore also mentions one overarching element in Mediterranean masculinity: personal autonomy. In order to fulfill a man's duties as mentioned earlier, a man needs to be autonomous. It is exactly this point which el-Limby does not experience and which also contributes to his fatalistic view on life. His experience is one of other people limiting his 
Networking Knowledge: Journal of the MeCCSAPostgraduate Network, Vol. 4, No. 1 (2011)

freedom of choice. The films thus portray a different masculinity than the ideals upheld by Mediterranean society. The descriptions offered by Gilmore are more generally talking about Mediterranean masculinity and surely Egyptian masculinities have their own peculiarities too. I want to stress that I do not claim anything about real-life Egyptian masculinities through an analysis of these films, I only analyze the films' parodying of masculine ideals. As mentioned earlier, studying what exactly is parodied in the films might tell us something about what Mohamed Saad and his characters think about these idealized masculinities.

\section{Futuwwa?}

El-Limby sees himself as the cool guy from the hood. He is acting like a futuwwa, a term which is translated in English sometimes as bully and sometimes as a chivalrous person (Salinger 1950; Jacob 2007). It is a known character in real life and very famous in Egyptian films as well (Malkmus and Armes 1991: 101-102). The contradictory translations are due to the fact that the term was applied to different kinds of men depending on the time and place. In case of el-Limby, he is trying to give himself an image of a bully, yet somehow chivalrous as well, and generally fails to convince the viewers.

Although el-Limby is a bully, he is certainly no baltagi (thug), a term which is used to refer to criminals and which is too harsh for a character like el-Limby. I see no reason to criminalize and penalize the character. In the end, he is not really breaking any laws (except using drugs, which is penalized in Egyptian law). When he is accused of stealing (Do You Remember?), he actually took back what was already his. Furthermore if he were labeled a criminal, the movies might be read as victimizing popular masculinity which is not the case either. Since as an audience we are asked to sympathize and empathize with el-Limby, the movies would be redeeming his 'criminal' acts. 


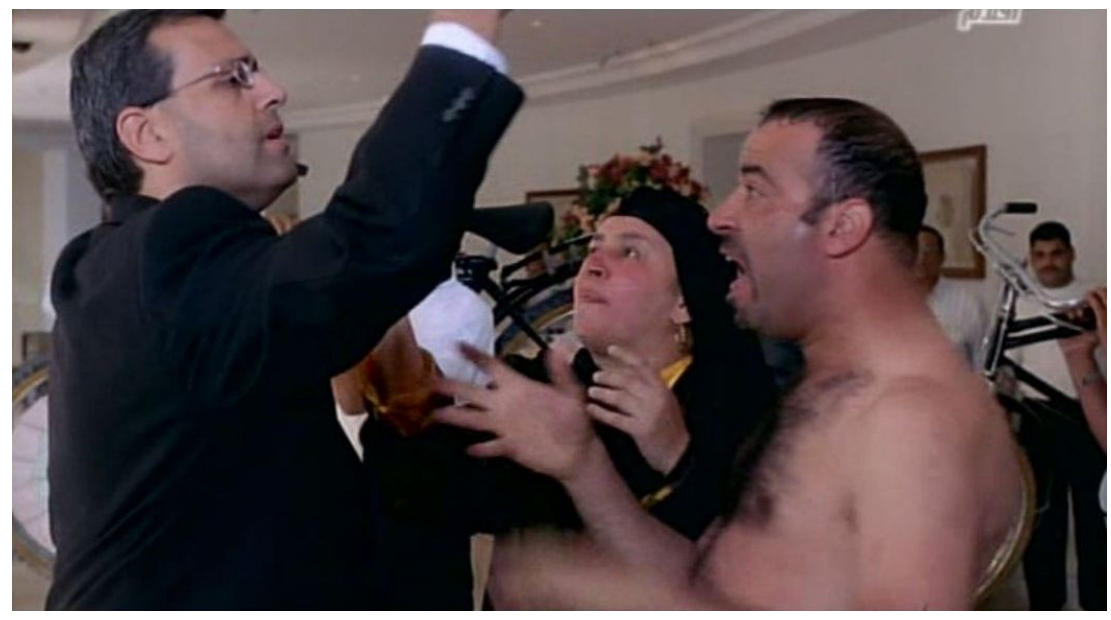

Figure 6: El-Limby getting ready to fight in El-Limby

But wanting to be a futuwwa is not without consequences. Contrary to the futuwwa as strongman, however, he turns out to be a coward on more than one occasion. In El-Limby he takes off his shirt to fight a hotel manager in Sharm el-Sheikh. Taking off his shirt in this case is a typical move for the character, as he does not want to have it ripped due to the fight. Afterwards, he wants to be able to put it back on so that nobody would see whether he got beaten up or not. And that is actually what happened, as the movie cuts to the next scene, conveniently omitting a confrontation between el-Limby and the guards at the hotel. Also in other films he takes off his shirt or shows off his muscles preparing for a fight.

In Do You Remember? he tells his wife to 'take the shirt and run' when he gets into a fight with several very muscular bullies. Also the character Booha in the film with the same name (Ramy Imam 2005) takes of his shirt when the fight gets serious, as does Katkoot when he is warming up for a boxing game. Other examples of boasting abound in his movies. An interesting observation however is that fights with other men are rarely shown in his movies and when they are, it is only briefly. Only Booha and Awkal (in Awkal, Mohamed el-Naggar 2004) are fighting male opponents a couple of times (bullies, the diamond mafia) while all his other characters are either running away or the fight is conveniently cut (after which he is seen 
wounded and taken care off). The fact that el-Limby himself and most other characters are rarely seen actually fighting other (stronger) men underlines the fact that he is a coward.

The emphasis here on 'stronger' is deliberate: Mohamed Saad's characters are always accompanied by weaker men. In Principal Salah al-Din, he is the one teaching Salah el-Din how to be respected by his students by acting and speaking in a specific way. El-Limby teaches him several key phrases to impress his enemies and he takes the new principal also to karate classes (in which he does not participate, evidently, out of fear of being beaten up). In Do You Remember?, his friend is a shy, scared person. Also Awkal's good friend is depicted as a weak character, involved in cinema and television and all the time beaten by Awkal's grandmother Atata (played by Mohamed Saad as well). When Booha goes to the city, he is helped by a pathetic crook. And Katkoot's buddy is again the same actor who played his unmanly friend in Do You Remember?. It seems he is surrounding himself with weak figures so that he comes out stronger, tougher, cooler, better looking, and simply more masculine.

He not only has problematic relations with men, but he also does not know how to deal with women. Firstly, the women in his films are depicted in negative stereotypes, apart from a few love stories. They are either extremely dominant mother figures or prostitutes, not immediately the most attractive of choices. Only three films offer a positive image of women. And it is not simply a positive image; for example, in the case of Noosa in El-Limby, she is also the driving force behind el-Limby's actions.

Apart from the negative stereotypes, el-Limby is moreover violent towards women in the films. The aggression directed at women is more visual and extensive than the fights with men. However, the women are not victimized per se in this way, they are actually quite empowered and are not afraid to confront him. His conduct towards women fits in his overall violent behavior towards people he considers to be weaker than him. Saad's characters emphasize violence towards weaker persons as part of their building their perceived masculine image. It is an example of how el-Limby, being marginalized in society, seeks to reproduce a 'dominant position'. 
Networking Knowledge: Journal of the MeCCSAPostgraduate Network, Vol. 4, No. 1 (2011)

A few examples will elucidate this point. ${ }^{10}$ In the film Booha he literally beats up two women. It is part of a scheme to take the son of a rich, corrupt merchant to court. Booha advises the two women to get beaten up and blame the boy and he is willing to give them a 'hand' and make it look realistic. Also in Katkoot he gets violent towards a foreign nurse who he at first believes to understand Arabic. When he tries to explain to her that he needs to go to the toilet, she obviously does not understand and wants him to get back into bed. At that point he becomes violent towards her and starts a fight. As he is fighting, her anguish is stressed by a close-up of her shouting, while the camera moves around briskly.

These fights are not to be misinterpreted as him being violent towards women in general; he simply does not know how to deal with them. Next to that he is a coward and only fights those who he thinks he can handle, those who he experiences to be less powerful and influential than him. That is why in his films he does not fight the women (and men!) whom he believes to be more powerful and more authoritative than him (el-Limby's mother, his rich wife in Do You Remember?, or his grandmother as well as the daughter of a rich merchant in Awkal). This account does not only show how violent he is towards others, it tells us moreover and more importantly where he positions himself in society.

\section{Identification or alienation?}

Now that we have a clearer view on the masculinity of Saad's characters, how does this relate to my question about identification? Considering that identification here is understood as aspectual identification, I argue that identification does occur with the Limby-character, but less so with the later characters. Here, Bertolt Brecht's notion of alienation is useful. Mohamed Saad has mastered the art of alienation as Brecht (1961) has defined it. He makes it clear in his movies that he knows he is being looked at: he almost goes into direct discussion with his spectators. He is demanding from his audience to react, to engage in the film, and not just sit and passively watch the story unfold itself.

\footnotetext{
${ }^{10}$ It needs to be remarked though that he is not violent in his earlier movies, El-Limby and Do You Remember?. This is one very distinguishing mark in the characters, where el-Limby himself is non-violent and the other characters became so. This is probably the director Wael Ihsan's influence in the films, since he directed both films.
} 


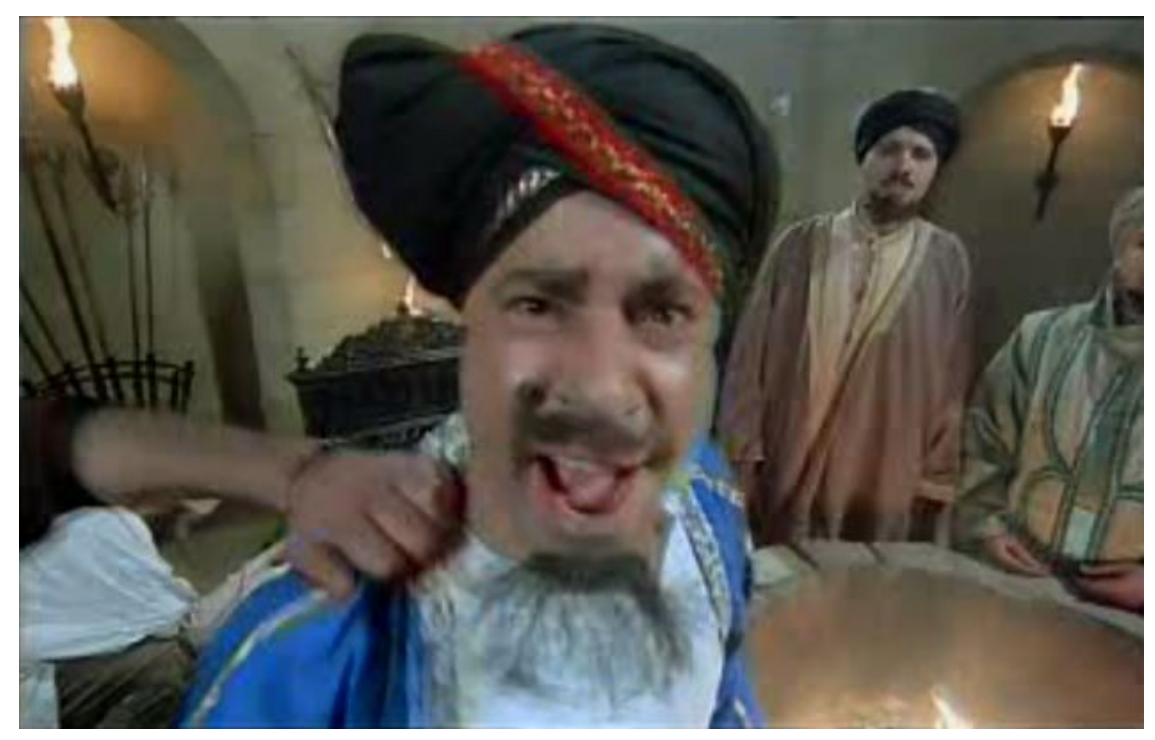

Figure 7: Breaking the illusion in Awkal

There are several scenes in his films where we as an audience notice we are watching a film, where the illusion is broken. One such scene is when Awkal is going to act in a film and we actually see all the cameras and staff on the set. Awkal here looks directly at the camera - at us and speaks to us, while a hand is entering the frame trying to pull him away. Even in El-Limby, where we are nevertheless asked to align ourselves with the character, he stumbles and falls out of the frame, focusing our attention on the fact that we are only watching through the eye of a camera and thus breaking the illusion we might have felt at first.

Although Saad's characters thus allow their public to experience cinema as an audience being aware that they are sitting in the theater and watching a film, demanding them to engage in it, this does not deny the viewer from sympathizing with the main character. We enjoy watching him, realizing it is only a film. We know that what is happening is not real, yet all the types and characters, as well as the stories that are shown, are recognizable and most of them at least somewhat realistic. His Limby-character was perhaps the most recognizable of all, as a personality present in Egyptian society which recently became more prevalent. 
Networking Knowledge: Journal of the MeCCSAPostgraduate Network, Vol. 4, No. 1 (2011)

This alienation is strengthened through the confusion the audience has while watching the films. The audience looks in vain for meanings behind the actions and references the movies make. Everything is recognizable yet not quite. There is always the feeling something is wrong.

\section{Conclusion}

Coming back to our question on identification with the main characters' masculinities, it is only one of the reasons for his declining popularity. The elements of the masculinities of Saad's characters are masculine looks in terms of hair; violence and boasting; childishly emotional; drinking, smoking and being sociable; and somehow feminine gestures and objectification of the body. These elements are part of all his characters, so in this sense they do not influence the public's identification with them. But as much as this specific masculine type, that el-Limby for sure was, used to be innovative, enticing and funny at first, so it became equally repetitive after a while. Perhaps the audience just grew tired of seeing him making jokes over and over again and was longing to watch films with a deeper message to it.

As I mentioned earlier in the discussion on futuwwa, the character might also be referred to as baltagi (thug). Since the Revolution in Egypt, the Mubarak-era has widely been described as an era where 'baltaga' (thuggery) and lawlessness was prevalent, and people very much enjoyed watching a comedic representation of what was real and recognizable in the streets. These themes, which people before only talked about, have recently been scrutinized in many Egyptian films in a quasi-political way. El-Limby as a character as well as the movie were both part of the discussion on these social themes. But this recognition of the character declined as Saad managed to alienate his viewers from his characters. He did this in several ways, but mostly by focusing on the characters' foolishness, funny faces and gestures, as well as through changing the characters' backgrounds.

When the characters developed and continued to lose touch with Saad's old neighborhood in Cairo, the popularity of the movies declined as well. However, it is premature to suggest a direct link between these developments, and more extensive interviews with people involved in producing the films as well viewers are needed. Presumably there are economic 
Networking Knowledge: Journal of the MeCCSAPostgraduate Network, Vol. 4, No. 1 (2011)

reasons as well, such as the recent steep increase in ticket prices. While downloading pirated copies of movies has become so much easier and more widespread, buying an expensive ticket for a single experience can withhold many people. But whatever stance one takes on Mohamed Saad's films, one might suggest that his provocative contributions to contemporary Egyptian cinema have exposed certain taboos and cleared the path for others to deal with them more openly.

\section{References}

Armbrust, W. (2011) 'Political film in Egypt.' In: Gugler, J., (ed.) Film in the Middle East and North Africa: Creative dissidence, Cairo: The American University in Cairo Press

Bordwell, D. (1989) Making Meaning: Inference and Rhetoric in the Interpretation of Cinema. Cambridge: Harvard University Press

Bordwell, D., and Carroll, N. (1996) Post-theory: Reconstructing Film Theory. Madison: The University of Wisconsin Press

Brecht, B., and Bentley, E. (1961) 'On Chinese Acting', The Tulane Drama Review, 6, 1: 130136

Butler, J. (2002) Gender Trouble: Feminism and the Subversion of Identity (Tenth Anniversary Edition). Taylor and Francis e-Library

Carroll, N. (1990) The Philosophy of Horror, or, Paradoxes of the Heart. New York: Routledge Connell, R. W. (2005) Masculinities (second edition). Cambridge: Polity Press

Daoud, H. (2006) 'Those Two Heavy Wings of Manhood: On Moustaches.' In: Ghoussoub, M., and Sinclair-Webb. E., (eds.) Imagined Masculinities: Male Identity and Culture in the Modern Middle East, London: Saqi Books, pp.273-280

Dyer, R. (1998) Stars. London: British Film Institute 
Networking Knowledge: Journal of the MeCCSAPostgraduate Network, Vol. 4, No. 1 (2011)

El-Messiri, S. (1978) Ibn al-Balad: A Concept of Egyptian Identity. Leiden: Brill

Freeland, C. A. (1996) 'Feminist Frameworks for Horror Films.' In: Bordwell, D., and Carroll, N., (eds.) Post-theory: Reconstructing Film Theory, Madison: The University of Wisconsin Press, pp.195-218

Gaut, B. (2006) 'Identification and Emotion in Narrative Film.' In: Carroll, N., and Choi, J., (eds.) Philosophy of Film and Motion Pictures: An Anthology, Oxford: Blackwell Publishing, pp. $260-270$

Ghoussoub, M., and Sinclair-Webb, E., (eds.) (2006) Imagined Masculinities: Male Identity and Culture in the Modern Middle East. London: Saqi Books

Gilmore, D. (1990) Manhood in the Making: Cultural Concepts of Masculinity. New Haven and London: Yale University Press

Ismail, S. (2009) 'Youth, Gender, and The State in Cairo: Marginalized Masculinities and Contested Spaces.' In: Khalaf, S., and Khalaf, R. S., (eds.) Arab Society and Culture: An Essential Reader, London: Saqi Books, pp.223-239

Jacob, W. C. (2007) 'Eventful Transformations: Al-Futuwwa between History and the Everyday', Comparative Studies in Society and History, 49, 3: 689-712

Kirkham, P., and Thumim, J., (eds.) (1993) You Tarzan: Masculinities, Movies, and Men. London: Lawrence and Wishart Ltd.

MacKinnon, K. (2003) Representing Men: Maleness and Masculinity in the Media. London: Arnold Publishers.

Malkmus, L., and Armes, R. (1991) Arab and African Film Making. London: Zed Books.

Menicucci, G. (1998) 'Unlocking the Arab celluloid closet: Homosexuality in Egyptian film', Middle East Report 206: 32-36

Neill, A. (1996) 'Empathy and (Film) Fiction.' In: Bordwell, D., and Carroll, N., (eds.) Posttheory: Reconstructing Film Theory, Madison: The University of Wisconsin Press, pp.175-194 
Networking Knowledge: Journal of the MeCCSAPostgraduate Network, Vol. 4, No. 1 (2011)

Salinger, G. (1950) 'Was the Fut' 'wa an Oriental Form of Chivalry?', Proceedings of the American Philosophical Society, 94, 5: 481-493

Shail, R. 2001. 'Masculinity and Visual Representation: A Butlerian Approach to Dirk Bogarde', International Journal of Sexuality and Gender Studies, 6, 1/2: 95-107

United Nations Development Programme, Institute of National Planning Egypt. (2010) Egypt

Human Development Report 2010: Youth in Egypt, Building our future, Available from: http://hdr.undp.org/en/reports/national/arabstates/egypt/name,20494,en.html [accessed 15.11.10]

\section{Newspaper articles}

Abd el-Fattah, E. H. 'Karkar wa amthalo' (Karkar and his examples), Al-Ahram: 25 July 2007 Adly, N. 'Sinima 2004: Iskandariyya New York al-afdal.. wa-ma zala Muhammad Saad al-a'la iradan' (Cinema 2004: Alexandria-New York the best... Muhammad Saad still tops box office), Al-Ahram: 29 December 2004

Adly, N. 'Sinima 2005: Al-Sifara fi 'l-'Imara al-afdal.. wa-Muhammad Saad yuhattim aliradat!' (Cinema 2005: Embassy in the Building the best... Muhammad Saad smashes box office!), Al-Ahram: 28 December 2005

Alaa el-Din, N. 'Siraa' $<<$ Heneidi - Saad $>>$ 'ala Wail Ihsan yantiqil li- 'l-drama' (Fight between Heneidi and Saad concerning Wail Ihsan develops into drama), Available from: http://www.rosaonline.net/Daily/News.asp?id=87020 [accessed 20.10.10]

Atef, A. 'Hal al-sinima mir'aat li 'l-wakia am masnaa li 'l-wahm?' (Is cinema a mirror of reality or a fantasy factory?), al-Ahram: 30 August 2006

El-Farooq, O. 'El-Mazaag el-Masry' (Egyptian mood), Al-Ahram: 27 September 2002

El-Saadani, A. 'Dor al-'ard yatala'ab bi 'l-aflam?' (Are theaters manipulating the films?), Al-Ahram: 7 August 2002 
Networking Knowledge: Journal of the MeCCSAPostgraduate Network, Vol. 4, No. 1 (2011)

Farouk, A. 'Muhammad Saad: Lan atanazal 'an al-Limby' (Muhammad Saad: I will not give up el-Limby), Al-Shorouk: 7 July 2010

Karawya, F. 'The Demise of 'Clean Cinema'?', Available from: http://www.almasryalyoum.com/en/node/20570 [accessed 05.10.10]

Moosa, M. 'Muhammad Saad.. Hal yakfi al-nagah al-gamahiry wahdo?' (Muhammad Saad..

Does public success alone suffice?), Al-Ahram: 14 August 2002

Moosa, M. 'Muhammad Saad: Katkoot Howa Mufaga'ati al-Gadida!' (Muhammad Saad:

Katkoot is My New Surprise!), Al-Ahram: 7 June 2006

'96 milyon gineh iradat al-aflam al-misriyya' (96 Million Egyptian pounds revenues of Egyptian films), Al-Ahram: 31 December 2003

'168 milyon gineh iradat al-aflam al-misriyya' (168 Million Egyptian pounds revenues of Egyptian films), Al-Ahram: 28 December 2005

'230 milyon gineh iradat al-aflam al-misriyya' (230 Million Egyptian pounds revenues of Egyptian films), Al-Ahram: 30 December 2006

\section{Movies}

Principal Salah el-Din (al-Nazir Salah ad-Din), 2000, Sherif Arafa, Cairo: Promise Film Production

El-Limby, 2002, Wael Ihsan, Cairo: El-Sobki Film Production

Do you remember? (Elli Baly Balak), 2003, Wael Ihsan, Cairo: El-Sobki Film Production

Awkal, 2004, Mohamed el-Naggar, Cairo: El-Sobki Film Production

Booha, 2005, Ramy Imam, Cairo: Oscar

Katkoot, 2006, Ahmed Ewaad, Cairo: Oscar

Karkar, 2007, Ali Ragab, Cairo: El-Sobki Film Production 